\title{
Glacial meltwater impounding: Evidence from the late Quaternary glaciogenic sediments in the Sangla valley, district Kinnaur, Himachal Pradesh, India
}

\author{
R K Ganjoo ${ }^{1 *}$ and $\mathrm{M} \mathrm{N} \mathrm{Koul}^{2}$ \\ ${ }^{1}$ Department of Geology, University of Jammu, Jammu 180 006, India. \\ ${ }^{2}$ Department of Geography, University of Jammu, Jammu 180 006, India. \\ *e-mail: ganjoork@rediffmail.com
}

\begin{abstract}
Sangla valley is situated at an altitude of $\sim 3500 \mathrm{~m}$ above mean sea level and lies in the Kinnaur district of Himachal Pradesh. It is fed by river Baspa, a tributary of river Sutlej, that entrenches through the Quaternary glaciogenic deposits before emerging out of the valley and joining the river Sutlej at Karcham. The unstratified to stratified glaciogenic deposits consist of large boulders to fine silt and are classified into four major depositional facies on the basis of sedimentary texture and depositional environment. The facies - basal conglomerates, debris flow, water/sheet flow and laminites - represents the change in the environment of deposition from glaciofluvial to lacustrine and also the extent of the glacier to the valley floor during late Quaternary.
\end{abstract}

\section{Introduction}

Kinnaur Himalaya forms the western extremity of the Himachal Himalayan range. A number of subsidiary valleys lie between the Zanskar Mountain range, Great Himalayan range and Dhauladhar range; one of them is the Sangla valley. The main glaciers of the Sangla valley are Karu, Jorya, Janapa, Naradu, Magsu and Shushang which are situated between altitudes of $4000 \mathrm{~m}$ and $6200 \mathrm{~m}$ above mean sea level (msl). The Sangla valley lies at the foot of the main snowfield of the Baspa group of glaciers (figure 1). The relative relief of the valley ranges between $3500 \mathrm{~m}$ and $4000 \mathrm{~m}$ above msl. River Baspa originates in the Arsomang and Baspa Bamak glaciers and travels $72 \mathrm{kms}$ through Sangla valley before joining the trunk river Sutlej, at Karcham.

\section{Geology of the Sangla valley}

The Karcham group of rocks, characterized by a suite of various metasedimentary rocks, are exposed in the Sangla valley. The group has quartzite and graphitic schist at the base followed by a thick sequence of psammitic gneiss, banded gneiss with kyanite, granitic gneiss and coarse psammitic gneiss that grades into Rakcham granite (Kakar 1988). Rakcham granite represents the basal part of the unfossiliferous Haimanta group (Precambrian) whereas the Karcham group is correlatable with the Vaikrita group (Proterozoic; $\sim 600 \mathrm{ma}$ ).

\section{Quaternary geology of the Sangla valley}

The Sangla valley preserves the remnants of glaciogenic deposits (maximum thickness $-25 \mathrm{~m}$ ) that have been incised, eroded and modified to a large extent. Nevertheless, thick successions of the glaciogenic deposits are exposed near the towns of Sangla, Kamru and Kupa (figure 1).

The glaciogenic deposits in the Sangla valley have not been dated yet. Nevertheless, thermoluminescence ages of glaciogenic deposits along the

Keywords. Late Quaternary; glaciogenic sediments; depositional environment; Baspa river; Kinnaur district; Himachal Pradesh. 


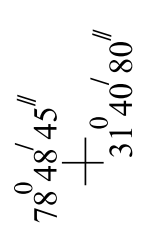
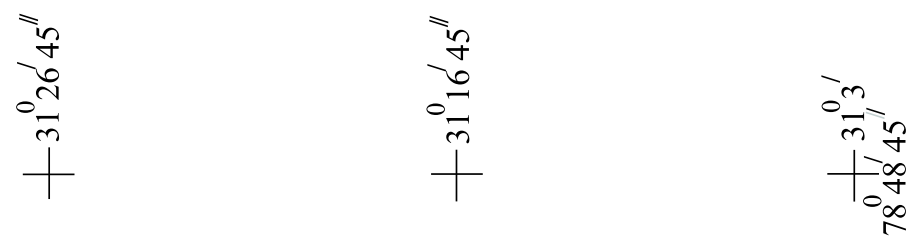

in

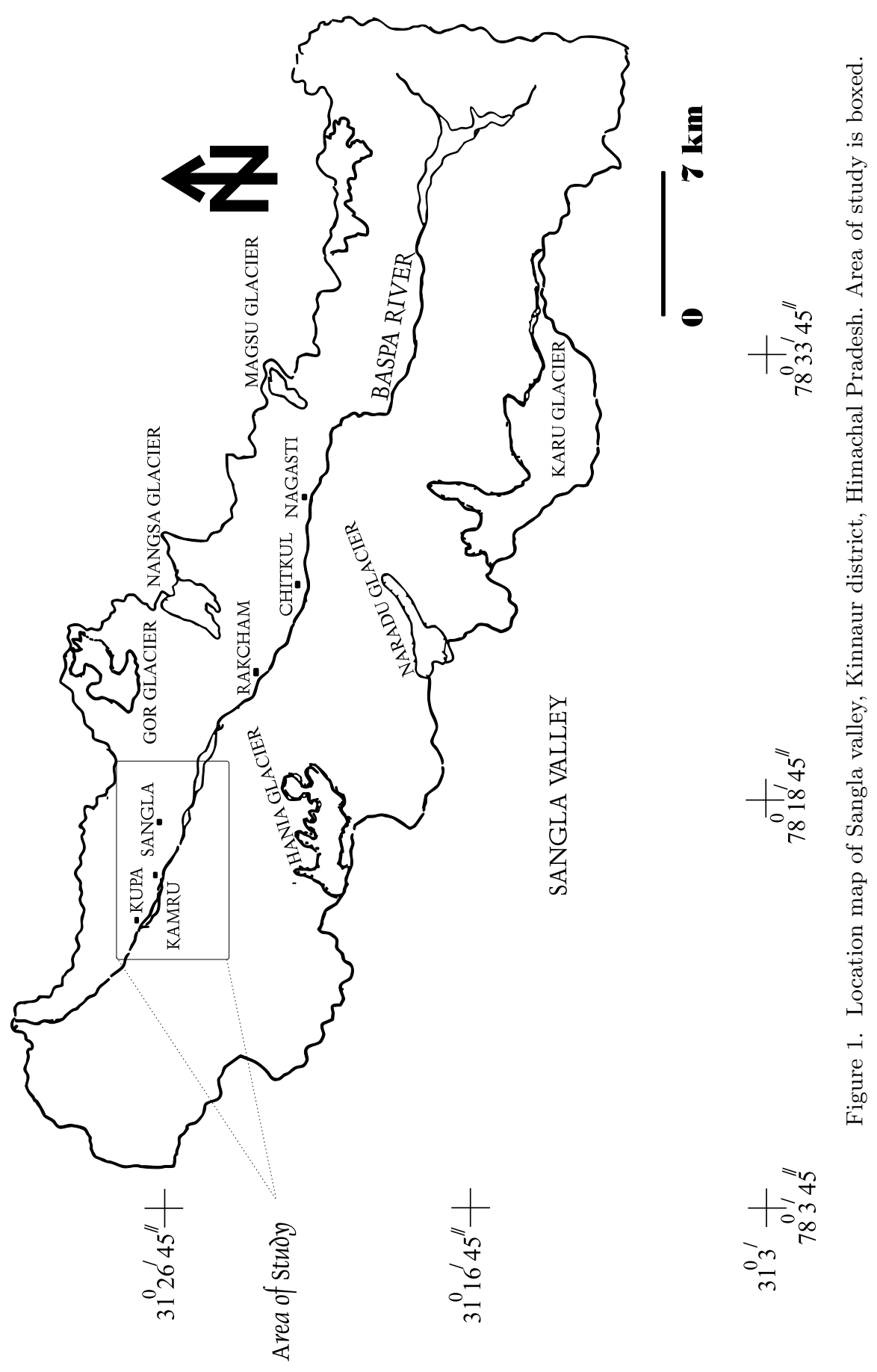


Kaurik-Chango fault zone near village Sumdo, an extension of glaciogenic deposits in the Sangla valley, are in the range of $90 \pm 10.5-26 \pm 4.3 \mathrm{ka}$ (Bagati and Mohindra 1997).

\section{Results and discussion}

Based on the standard textural analyses and study of sedimentary structures, we have divided the late Quaternary glaciogenic deposits in Sangla valley into (A) basal conglomerate, (B) cohesive debris flow, (C) sheet/water flow and (D) laminites.

\subsection{Facies A: Basal conglomerates}

Conglomerates overlie the valley floor (figure 2). They consist of an unsorted but clast-rich mixture of granules, medium to coarse sand, pebbles, cobbles and boulders. The matrix is composed of poorly sorted pebbly coarse sandstone. The conglomerates are ungraded and have a poorly organised fabric with long axes variably oriented from vertical to horizontal. The boulder blocks reach the size of $2-3 \mathrm{~m}$ in length. The lack of stratification or

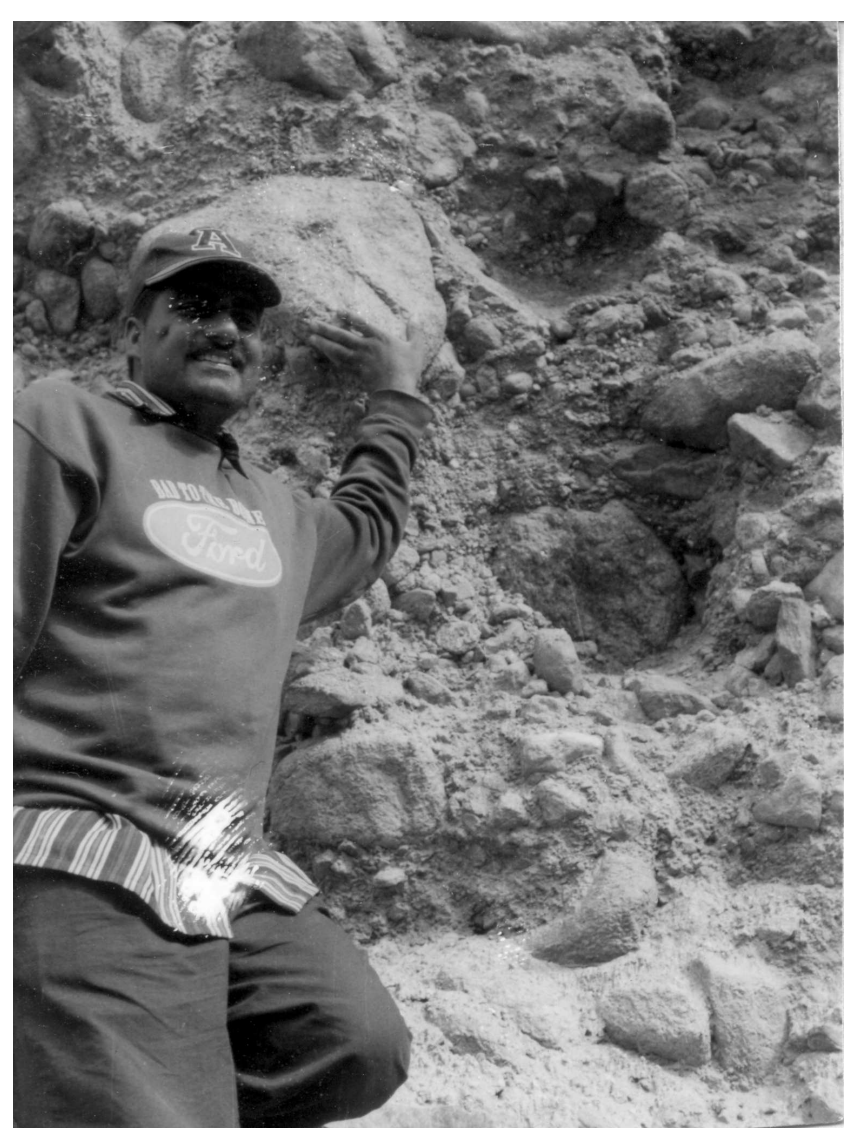

Figure 2. Basal conglomerates (facies A) exposed on the right bank of river Baspa downstream of Sangla town. The asssorted, un-oriented nature of sediments and other sedimentary features suggest their glaciogenic origin. sorting and the disorganised boulder fabric differentiate them from sediment gravity flows or water flows. The fabric and structure of sediments suggest the movement of blocky material from steep slopes to the valley floor and their deposition as moraines that underwent subsequent modification by meltwater streams.

\subsection{Facies B: Cohesive debris flow}

It consists of sorted to well-sorted and weakly to well-stratified mixture of silt to pebble grade particles (figure 3). The facies locally exhibits a clastsupported texture along the channel margins but it is mainly matrix-supported. The facies exhibits moderately to well-developed coarse-clast fabric with long axes of boulders/cobbles having a preferred horizontal alignment. The beds are lenticular and relatively extensive (25-30 m long). The base of the beds is non-erosive and follows the topography that was available for deposition. Many beds show 'coarse-tail' inverse grading. We interpret the rounded gravels and sandy gravels as reworked glaciofluvial deposits. The high proportion of rounded to well-rounded clasts and the lack of striated or faceted clasts are two lines of evidence for the reworking of deposits. Crude planar bedding is apparent from variations in modal particle size. Particle size analysis shows that the matrix is composed mostly of medium to very coarse sand and granules to medium pebbles. Abundant pebbles, at places, display an imbricate fabric. Beds with differing particle size reflect variations in flow strength whereas sandy lenses represent deposition from shallow, waning flows. The bedforms, sorting, clast support and imbrication of the deposits

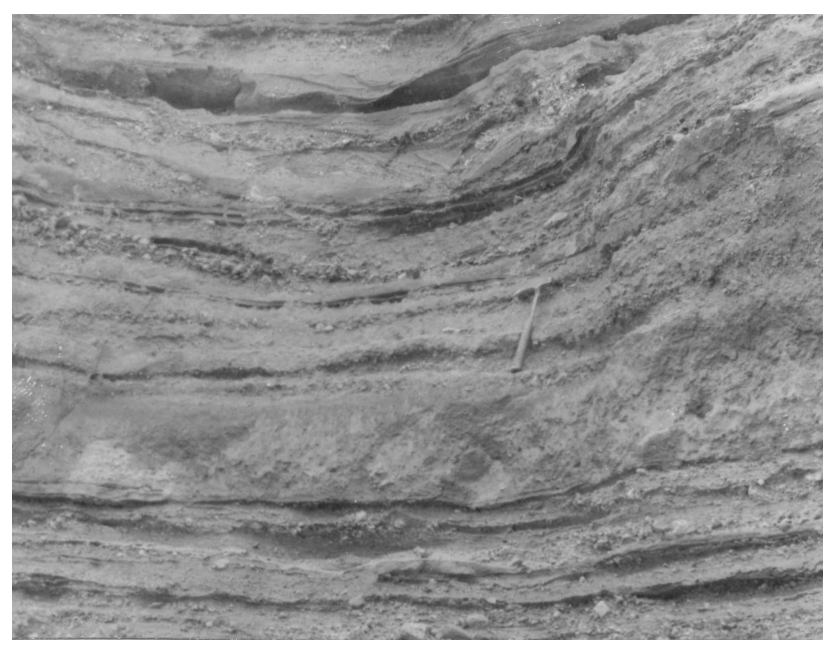

Figure 3. Debris flow (facies B) exposed between Sangla town and Kamru village. The particles of these deposits are well-sorted and oriented and the size of clasts is much smaller than that of facies A. The sedimentary structures and texture identify it as debris flow deposits. 
suggest that the depositional environment was cohesive debris flows of high to moderately-high viscosity caused by accumulated water flow.

\subsection{Facies C: Sheet/water flow}

This facies consists of lenses of well-sorted, medium to coarse sand with faint to distinct plane-parallel stratification. The beds have weakly erosive bases and contain isolated cobbles or boulders. The wellsorted sand (0.5-2 m thick) forms an arcuate belt. The well-sorted nature, sedimentary structures and location of the sand body are suggestive of tractional deposition from poorly confined water flow apparently in the upper regime, reflecting sheet flow processes. The characteristics of the deposits imply that the sand body is a glacially reworked fluvial deposit that could have formed relative to the receding glacier.

\subsection{Facies D: Laminites}

The fine grained facies (figure 4) comprises laminites. It is a clast-free, laminated, very fine silt to very fine sand. The laminae are typically 1-3 mm thick and at places highly deformed into large overturned folds. Laminites are continuous over distances of $>1 \mathrm{~m}$, although convoluted laminations are also present at places. The deformation of laminations is a result of earthquake-induced liquefaction (Bagati 2001).

In terms of relative abundance, the dominant lithofacies are sandy-boulder gravel and sandy gravel, typical of ice-marginal and glaciofluvial environments respectively (Benn and Evans 1998). Sedimentary evidence suggests an incredibly high

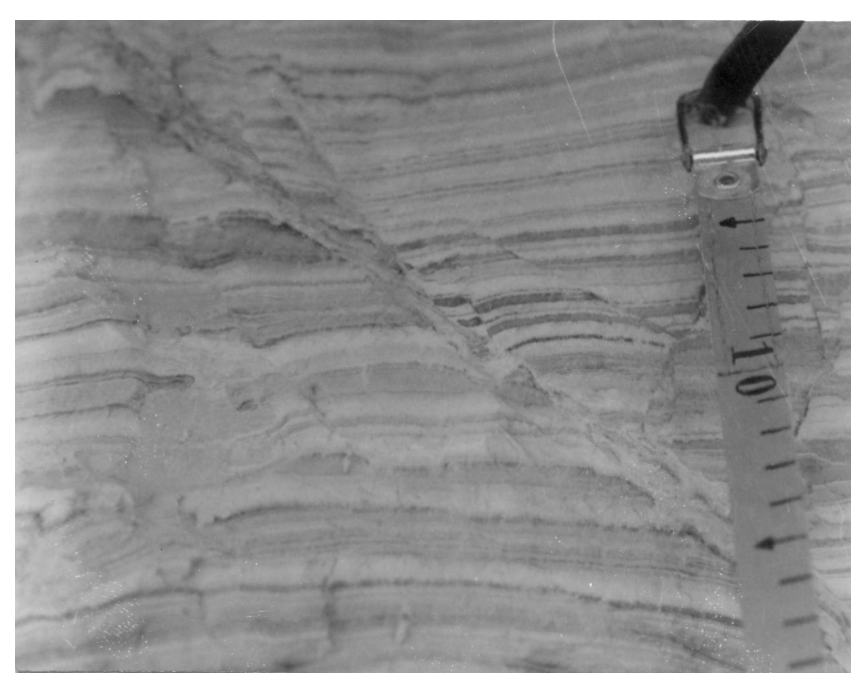

Figure 4. Laminites (facies D) exposed down of village Kupa. The fine alternate laminae of sand and silt suggests a lacustrine environment. The earthquake-induced liquefaction has caused the deformation of laminae. fluvial deposition rate that could be a catastrophic drainage event. Pebbly sandstone and conglomerates that dominate the basal conglomerate facies were deposited from flows saturated with suspended coarse-grained load. Different lines of evidence suggest that most of the debris transported by the valley glacier was derived from mass wasting of valley walls (Glasser and Hambrey 2002) for which floods acted as a trigger (Blair 1999). Depending on the content of mud, the colluvium transformed into mud flow or debris flow producing sheet flows or debris flows (Blair 2000). Thus, the lower part of the glaciogenic deposit in the Sangla valley represents catastrophic deposition that may be related to a major tectonic/climatic event.

The presence of ice-proximal lakes with a single outlet constrained by bedrock and the large moraine complex, ensures that meltwater ponded at the ice margin rather than creating a sandur plain (an outwash plain in glacial environments, especially at high latitudes, that is exposed to drastic wind activity) immediately in front of the glacier.

\section{Conclusions}

This study adds to the understanding of landform/sediment assemblages in temperate glaciated mountainous areas. The debris flow deposits that follow the basal conglomerates are suggestive of humid conditions whereas the water flow deposits indicate frequent but modest run-off limited to surficial lows. The reddish brown colour of the debris flow and water flow deposits imply intense weathering under warm and humid climatic conditions, of mountain ranges that have been the major source of sediment supply. The laminites are interpreted as glaciotectonic ice-proximal glaciolacustrine deposits caused by the damming.

The facies association also provides evidence of fluctuation of glaciers in Sangla valley. The presence of glaciolacustrine and glaciofluvial sediments implies that the basal conglomerates are a result of the maximum extent of glacier advance to the valley floor as evidenced from other parts of Himalaya as well (Swat, Nanga Parbat, Hunza, Zanskar, Garhwal, Lahul Khumbu, Kanchenjunga) (Richards et al 2000; Owen et al 2002).

\section{Acknowledgements}

This work is part of a research project (ES/91/03/96) funded by the Department of Science and Technology, Government of India. The authors thank the two anonymous referees for their valuable suggestions and comments. 


\section{References}

Bagati T N 2001 Imprints of paleoseismicity on soft sediment deformation structures in late Quaternary sediments in parts of Spiti and Kinnaur (HP). In: Research Highlights in Earth System Science, DST's Spl. Vol. 2 on "Seismicity" (ed.) O P Verma, pp. 123-129. Indian Geological Congress, Roorkee.

Bagati T N and Mohindra R 1997 Paleoseismic records in the form of soft-sediment deformation structures in late Quaternary sediments in parts of Spiti and Kinnaur (HP) (Abstr) - Indo-US Workshop on Paleoseismicity, pp. 68-69, Wadia Institute of Himalayan Geology, Dehra Dun.

Benn D I and Evans D J A 1998 Glaciers and Glaciation. Arnold, London, p. 734.

Blair T C 1999 Sedimentology of the debris-flow dominated Warm Spring Canyon alluvial fan, Death Valley, California; Sedimentology 46 941-965.
Blair T C 2000 Sedimentology and progressive tectonic unconformities of the sheetflood-dominated Hell's Gate alluvial fan, Death Valley, California; Sedimentary Geology 132 233-262.

Glasser N F and Hambrey M J 2002 Sedimentary facies and landform genesis at a temperate outlet glacier: Soler Glacier, North Patagonian Icefield; Sedimentology 49 43-64.

Kakar R K 1988 Geology and tectonic setting of central crystalline rocks of southern part of Higher Himachal Himalaya; J. Geol. Soc. India 31(2) 243-250.

Owen L A, Finkel R C and Caffee M W 2002 A note on the extent of glaciation throughout the Himalaya during the global Last Glacial Maximum; Quaternary Science Reviews 21 147-157.

Richards B W, Owen L A and Rhodes E J 2000 Timing of Late Quaternary glaciations in the Himalayas of northern Pakistan; Journal of Quaternary Science 15(3) 283-297. 